\title{
26. THE SHEETED DIKE COMPLEX IN HOLE 504B: OBSERVATIONS FROM THE INTEGRATION OF CORE AND LOG DATA ${ }^{1}$
}

\author{
P.K.H. Harvey, ${ }^{2}$ P. Pezard ${ }^{3}$ G.J. Iturrino, ${ }^{4}$ L.O. Boldreel, ${ }^{5}$ and M.A. Lovell ${ }^{2}$
}

\begin{abstract}
Continuous wireline log data obtained during Leg 140, together with some similar data from Leg 111, have been used in an attempt to place some constraints on the sequence of sheeted dikes encountered in Hole 504B. Resistivity logs, temperature logs obtained immediately after the cessation of drilling, and selected geochemical logs (alumina, ferric iron, and gadolinium) show a systematic and regular pattern throughout the bottom $1000 \mathrm{~m}$ of the hole where the sheeted dike sequence occurs. In particular, there is an apparent inverse relationship between the post-drilling thermal gradient and resistivity, which we interpret to result from a combination of the sequence of dikes (coarse/fine, with/without chilled margins) and the variations in their physical properties in response to drilling. With the limited log data available, our conclusions are of a qualitative nature, and a thorough study of this type, with a comprehensive set of logs, is necessary before any realistic interpretation of the sheeted dike complex in Hole 504B can be achieved.
\end{abstract}

\section{INTRODUCTION}

Hole 504B is located $200 \mathrm{~km}$ south of the Costa Rica Rift spreading center in the Eastern Equatorial Pacific and is currently the deepest hole drilled by the Ocean Drilling Program. At this time it is the nearest we have to a complete section through the oceanic crust with a $274.5-\mathrm{m}$ layer of sediments underlain by some $600 \mathrm{~m}$ of basaltic pillow lavas and below that a sheeted dike complex. A transition zone of about $200 \mathrm{~m}$ is recognized between the lavas and the dike complex. Through the Deep Sea Drilling Project (DSDP) and the Ocean Drilling Program (ODP) Hole 504B has now been drilled on seven different legs. A primary objective of the last two legs (140 and 148) was to penetrate through the sheeted dike complex and into the presumed underlying gabbros. At the end of Leg 140 the bottom of the hole lay at $2000.4 \mathrm{mbsf}$, the lower kilometer being virtually entirely within the sheeted dike complex.

Core recovery throughout Hole 504B has generally been poor and tends to get worse with increasing depth. Average recovery prior to Leg 140 was about $15 \%$, dropping to $12 \%$ for Leg 140 . Recovery is not only poor but it is also sporadic, varying from zero to over $40 \%$ per core barrel on Leg 140. Whereas a good picture of the volcanic stratigraphy above the transition zone has now been obtained through the integration of core measurements (particularly geochemical) and information from wireline logs (particularly electrical, Pezard and Anderson, 1989; Pezard, 1990), evaluation of the sheeted dike complex awaits similar treatment. In comparison with the essentially horizontal volcanic cover, the dike complex is composed of nearly vertical units; the density of geochemical and related petrographic core data is much lower than in the volcanics, and problems arise in the interpretation of the wireline logs that are akin to those encountered in horizontal wells. In addition, log data available for the lower part of the hole, as drilled during Legs 137 and 140, are severely limited. The interpretation of the dike complex lies, at least in part, in the recognition of the dike sequence. With poor core recovery, model

'Erzinger, J., Becker, K., Dick, H.J.B., and Stokking, L.B. (Eds.), 1995, Proc. ODP. Sci. Results, 137/140: College Station, TX (Ocean Drilling Program).

${ }^{2}$ Borehole Research, Department of Geology, University of Leicester, Leicester LEI 7RH, United Kingdom.

${ }^{3}$ Institut Méditerranéan de Téchnologie, Téchnopole de Château-Gombert, 13451 Marseille Cedex 13, France.

${ }^{4}$ Rosenstiel School of Marine and Atmospheric Science, Marine Geology and Geophysics, University of Miami, 4600 Rickenbacker Causeway, Miami, FL 33149-1098. U.S.A.

${ }^{5}$ Geological Survey of Denmark, Thoravej 8, DK-2400 Copenhagen, NV, Denmark. sequences may be proposed, but, with over $85 \%$ of the rock record missing, much of the interpretation inevitably will be hypothetical and difficult to test. Wireline log data should be able to close this gap. This contribution reviews the available wireline log data that were available at the end of Leg 140, and concentrates on the part of Hole 504B lying between 1000 and $2000 \mathrm{mbsf}$. We have used these data together with selected core measurements to try to place some constraints on the makeup of the dike complex.

\section{AVAILABLE LOGGING DATA}

Immediately after drilling was completed at the end of Leg 140 a series of logs was run to characterize the newly drilled portion of Hole 504B. The first logging run was temperature, which was measured from 19 to $2000 \mathrm{mbsf}$, reaching a maximum at the bottom of the hole of $141{ }^{\circ} \mathrm{C}$. This temperature profile is shown in Figure 1. Because the temperature was measured immediately after drilling ceased, it is far from an equilibrium profile but shows the extent to which the hole was cooled during drilling. Temperature also was measured over the interval 200 to $550 \mathrm{mbsf}$ some weeks earlier and immediately after the first re-entry to the hole. This short $\log$ is also shown in Figure 1. An equilibrium bottom temperature, by extrapolation from this earlier undisturbed temperature profile, should be about $200^{\circ} \mathrm{C}$.

The profile in Figure 1 also shows several other features that are dependent on the physical state and properties of the drilled formations. The reversal of the temperature gradient just below the sedimentbasement interface (discussed elsewhere in this volume by Boldreel et al. and Gable et al.), which was measured on arrival at the site some weeks earlier, was still present, though less accentuated, and a progression of slight changes in the average measured gradient can be seen as the profile passes into and then out of the transition zone between the volcanic sequence and the underlying sheeted dike complex. At about 1900 meters below seafloor (mbsf) the logged gradient increases sharply into the vicinity of the last part of the hole to be drilled. Superimposed on the broad temperature profile are a number of small scale features where there are rapid changes in gradient, often leading locally to inversion of the profile. These features are most clearly seen in logs of the temperature gradient, which are presented later (see Figs. 3 and 8).

Temperature was measured using a high-resolution temperature tool designed at the Bureau de Recherche Géologiques et Minières (BRGM), France. The tool uses accurately calibrated thermistors housed in a 5-mm-diameter tube in the lower part of the sonde. Temperatures were determined from the resistance of the thermistors. 


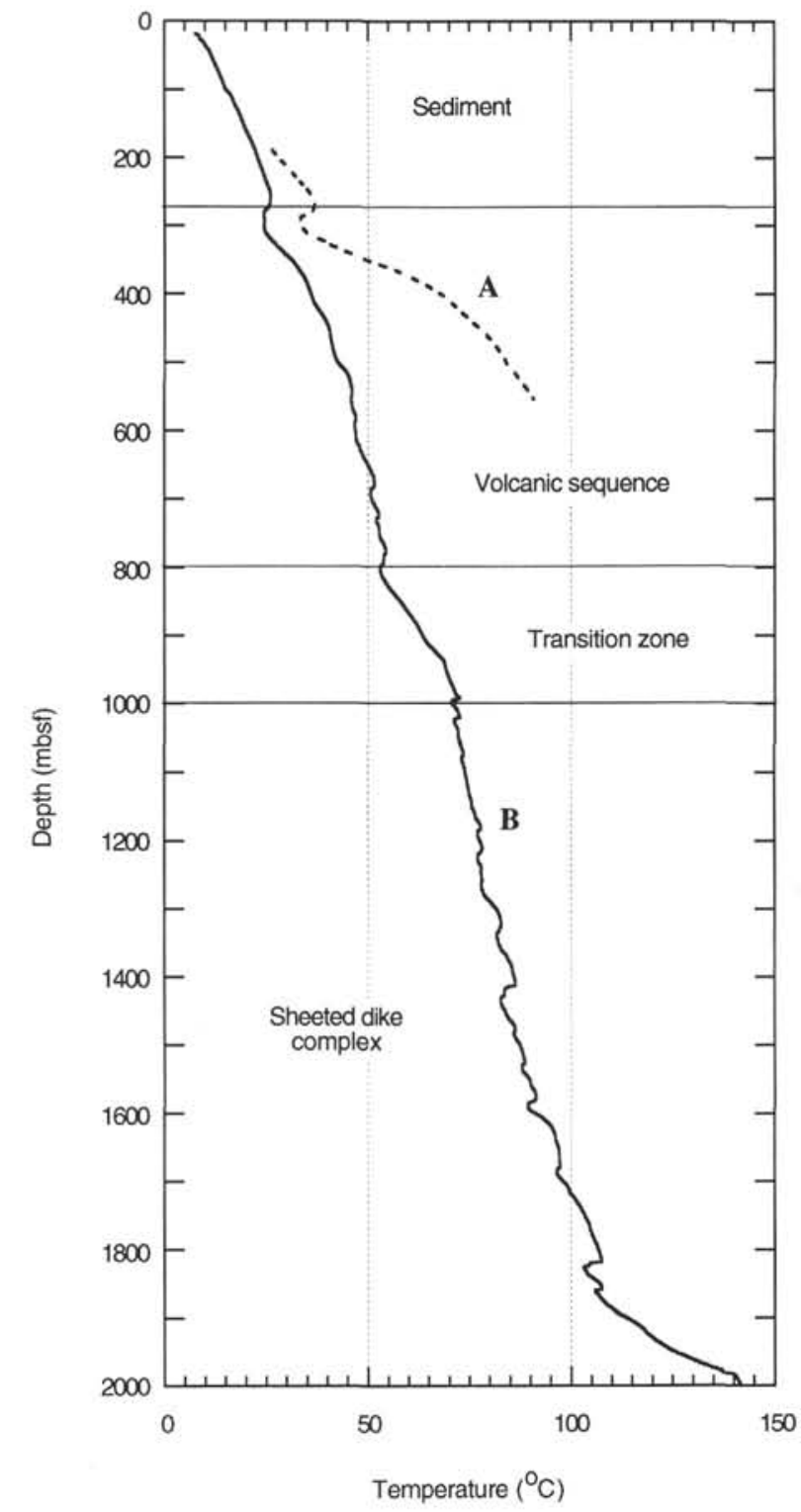

Figure 1. Temperature logs for Hole 504B measured during Leg 140: A. Immediately after re-entry into the undisturbed borehole. B. Immediately after drilling ceased toward the end of the leg.

For the logging operations during Leg 140, measurements were performed at $15 \mathrm{ft} / \mathrm{min}(4.57 \mathrm{~m} / \mathrm{min})$, which provided temperature estimates every $0.1 \mathrm{~m}$.

At the time of the post-drilling temperature logging, measurements were performed until the sonde touched bottom. The actual bottom-hole depth recorded at the winch at this point was 2002.9 mbsf, some $2.5 \mathrm{~m}$ in excess of the official bottom depth. It is not possible to make any accurate checks on the depth of individual measurements with the temperature tool other than at the rig floor and, by comparison, at the bottom of the hole. Assuming that the observed difference in the bottom-hole figures is close to the maximum error in the depth measurement on the temperature log, then the latter should be accurate to within about $2 \mathrm{~m}$.

The only other logs run over the whole $2000 \mathrm{~m}$ of Hole 504B were a sonic and resistivity combination. Due to technical problems, only one of the logs produced acceptable data; this was the shallow laterolog or $\mathrm{LL}_{\mathrm{s}}$. Excellent $\mathrm{LL}_{\mathrm{s}}$ and $\mathrm{LL}_{\mathrm{d}}$ (deep laterolog) curves were obtained previously on Leg 111 and have been described, particularly in relation to the volcanic sequence, by Pezard and Anderson (1989).
These Leg 111 logs are available down to 1275 mbsf. The laterolog data obtained during Leg 140 extend only the $\mathrm{LL}_{\mathrm{s}}$ curve to almost 2000 mbsf. The Leg $140 \mathrm{LL}_{\mathrm{s}}$ curve for the whole of Hole 504B is shown in Figure 2. The resistivity is relatively low ( 5 to $15 \mathrm{ohm}-\mathrm{m}$ ) through the volcanic sequence, rising at discrete intervals to values of more than $30 \mathrm{ohm}-\mathrm{m}$ that mark the position of a set of massive lava flows (Pezard, 1990). Through the transition zone, resistivity increases sharply to more than $40 \mathrm{ohm}-\mathrm{m}$, and thereafter increases gradually but irregularly. Typical resistivities at $2000 \mathrm{mbsf}$, at the end of Leg 140, are 250 to 300 ohm-m.

Geochemical logs were run over the sections drilled during Legs 137 and 140. Because of technical problems associated with overheating, the geochemical logs were run in two parts; they were processed separately (see Pratson et al., this volume) but merged for the purposes of this contribution. The first part included the sections between 1896 and 1811 mbsf and also between 1686 and 1350 mbsf. The second part was run over the interval 1826 to 1648 mbsf.

The available data covering the greater part of the dike complex at the end of Leg 140 are hence limited to the $\mathrm{LL}_{\mathrm{s}}$ laterolog curve, the "end of drilling" temperature curve, and the geochemical logs. The geochemical logs are somewhat restricted in their use because of the very limited range of compositions present in the dikes, so initial interpretation is focused on the relationship between the $\mathrm{LL}_{\mathrm{s}}$ and temperature curves.

\section{SHALLOW LATEROLOG RESISTIVITY AND TEMPERATURE}

Figure 3 shows the variation in the $L_{\mathrm{s}}$ resistivity and the temperature gradient for the sheeted dike interval: 1000 to $2000 \mathrm{mbsf}$. For clarity the two curves have been smoothed over 3-m intervals; the smoothing was performed using simple moving averages over the resistivity and gradient curves, respectively. We carefully compared the original and smoothed curves for both logs to ensure that the essential character and position of each curve was accurately preserved. The irregular pattern of increasing temperature (Fig. 1) is seen in Figure 3 as a sequence of inversions or local negative gradients; these appear to occur at reasonably regular intervals. The resistivity curve oscillates in a similar manner, the resistivity "highs" frequently being matched by a corresponding reversal in the temperature gradient. This correspondence is particularly clear between 1400 and 1800 mbsf; above this the temperature reversals occur at slightly lower depths than do possibly matching resistivity peaks, whereas below about $1850 \mathrm{mbsf}$ any relationship is masked by the sharp increase in temperature and its effect on the gradient curve. Some of the more obvious gradient/resistivity pairs are shown by arrows in Figure 3 . The resistivity log for the section of the hole drilled during Leg 140 is expanded in Figure 4, together with a plot of the core recovery during that leg.

Even where the resistivity peaks apparently correlate with reversals in the temperature gradient, the local temperature minima actually occur at a slightly greater depth (by a few meters). The reason for this is illustrated in Figure 5, where a short section is shown in detail between 1500 and 1600 mbsf. Over this interval the temperature, temperature gradient and resistivity $\left(\mathrm{LL}_{\mathrm{c}}\right)$ are shown together. There are three distinct resistivity peaks within this section with corresponding gradient inversions; the temperature minima corresponding to any gradient inversion occurs at a still slightly greater depth. This gives an offset of a few meters between the resistivity highs and associated temperature anomalies. For the three peak combinations in Figure 5 $(1,2$, and 3$)$ the differences between the resistivity peaks and corresponding temperature anomalies are $5.4,4.5$, and 6.7 to $16.8 \mathrm{~m}$, respectively, the last variation arising from the broad resistivity peak. These are not great differences in depth, but are generally greater than the errors that may be present in the depth estimates for both logs.

The local temperature inversions are probably due to the occurrence of either highly fractured or porous zones or regions of break- 


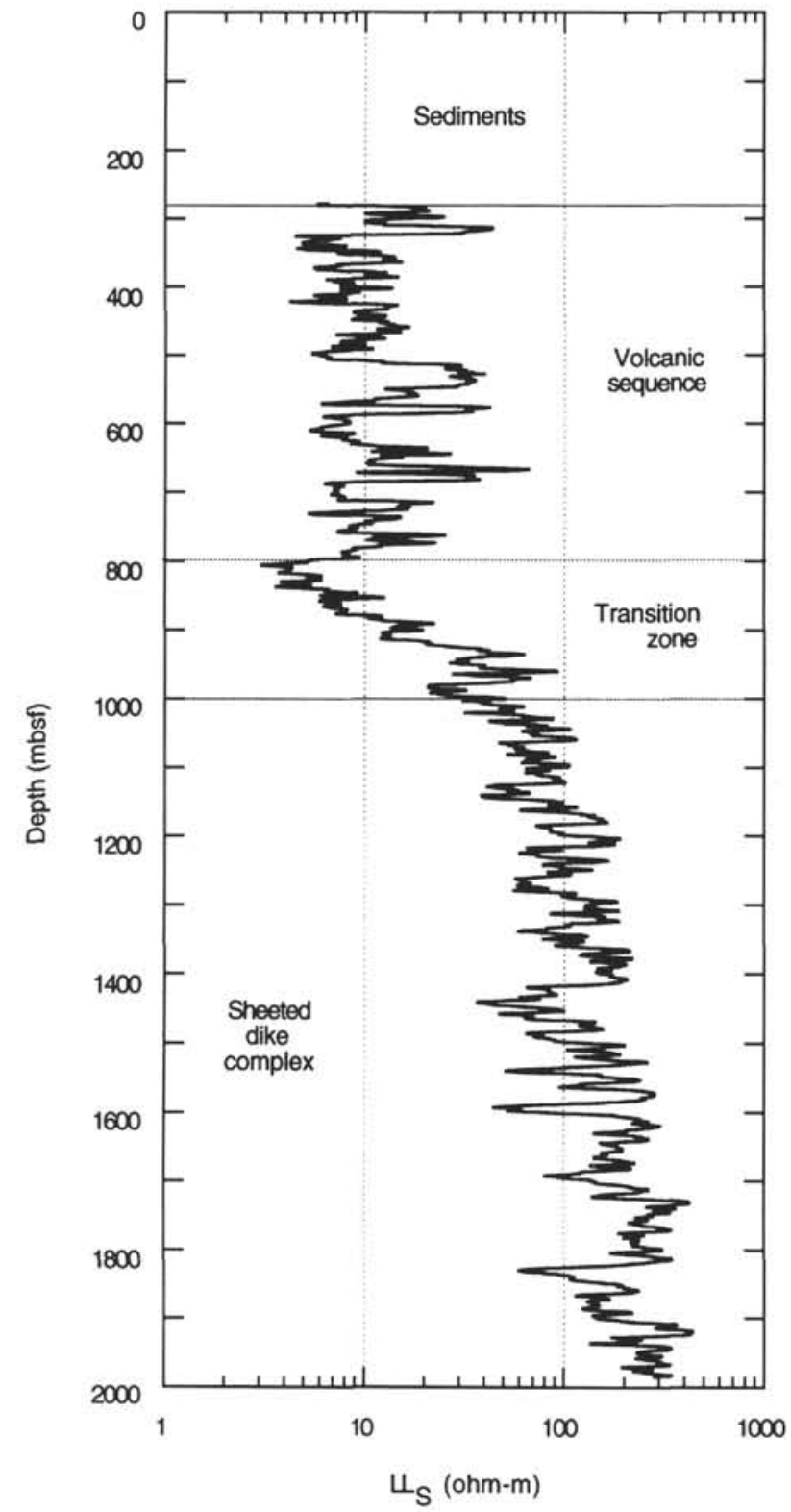

Figure 2. Shallow laterolog resistivity $\left(\mathrm{LL}_{\mathrm{s}}\right)$ curve for Hole 504B measured during Leg 140.

out. In the presence of such poor borehole conditions, there is increased space for volumes of water that are cooler than the surrounding rocks following the recent drilling and circulation. These, in turn, appear as lower temperature regions on the temperature log. In the absence of a caliper log, which would probably clarify the condition of the borehole, there is some additional evidence that is consistent with local fracturing, or at least increase in borehole diameter. This comes indirectly from the geochemical logs.

\section{DOWNHOLE GEOCHEMISTRY}

In the volcanic section at the top of Hole 504B, a moderate variation in bulk formation chemistry is characterized by the geochemical logs and results from the effects of alteration (Harvey and Lovell, 1989; Brewer et al., 1992). Within the dike section the formation is more constant in composition, with progressively less variation due to alteration toward the bottom of the section. This variation is, overall, generally less than the elemental precision offered by the geo-

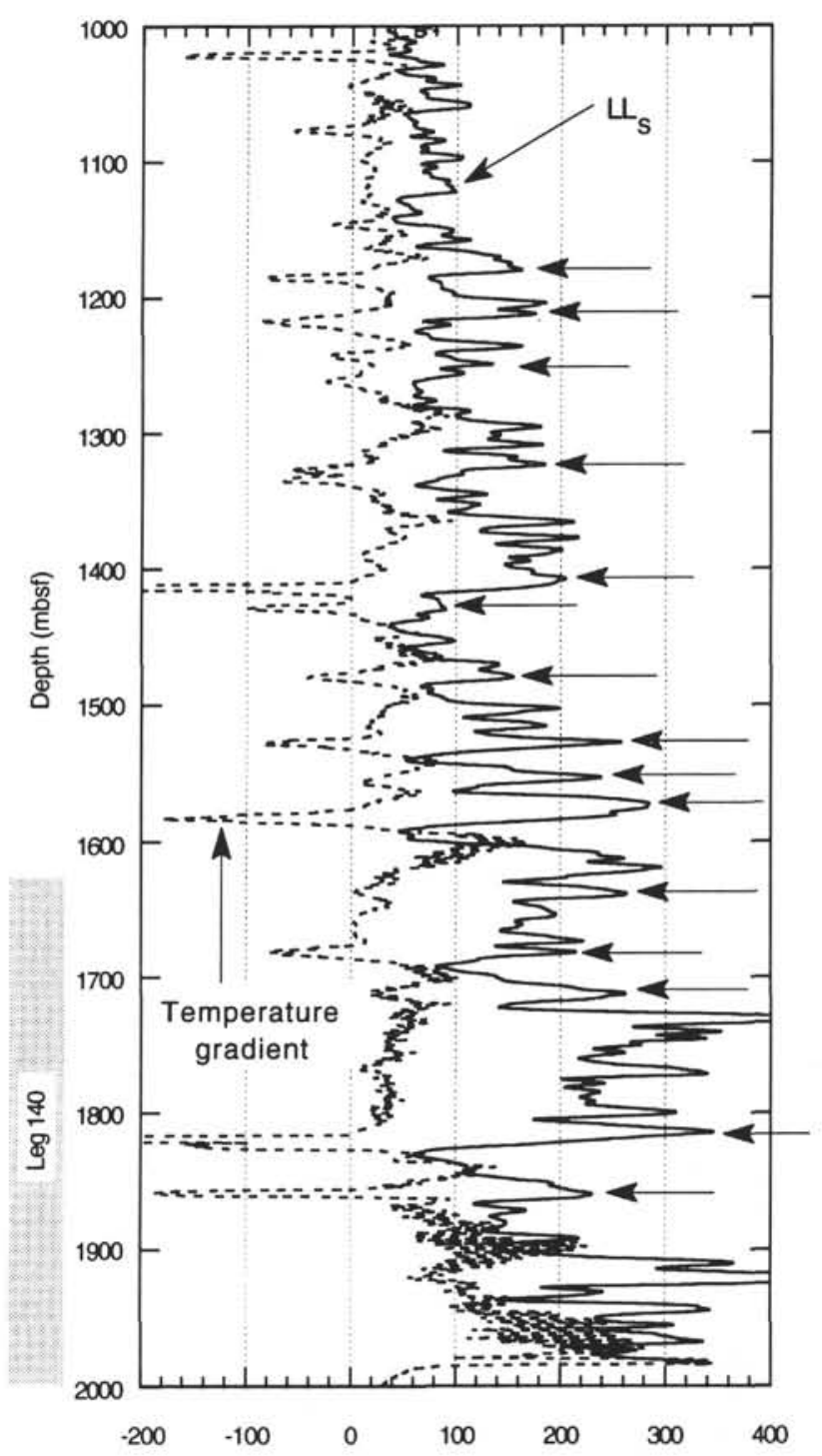

Figure 3. Variation in shallow laterolog resistivity $\left(\mathrm{LL}_{\mathrm{s}}\right)$ and temperature gradient for the bottom $1000 \mathrm{~m}$ of Hole 504B covering the sheeted dike complex. $\mathrm{LL}_{\mathrm{s}}$ is expressed in ohm-m. Temperature gradient is scaled for plotting purposes by a factor of 500 . Some of the more obvious resistivity peak/temperature inversion pairs are indicated by arrows.

chemical logging tool (GLT). It is not surprising, therefore, that the GLT curves show little systematic variation through this section (see Pratson et al., this volume). Exceptions to this are alumina, ferric iron, and gadolinium. Figure 6 shows the variation in $\mathrm{Al}_{2} \mathrm{O}_{3}$ and $\mathrm{LL}_{\mathrm{s}}$ for the section 1350-1700 mbsf where a strong correlation between the two curves is apparent. Figure 7 shows the same section for $\mathrm{Fe}_{2} \mathrm{O}_{3}$ and $\mathrm{LL}_{\mathrm{s}}$ where a weaker but distinct antipathetic relationship is seen. $\mathrm{Fe}_{2} \mathrm{O}_{3}$ and $\mathrm{Gd}$ are highly correlated, and $\mathrm{Gd}$ varies antipathetically with $\mathrm{LL}_{\mathrm{s}}$ in a similar manner to $\mathrm{Fe}_{2} \mathrm{O}_{3}$. None of the other elements $\left(\mathrm{SiO}_{2}, \mathrm{CaO}\right.$, $\mathrm{K}_{2} \mathrm{O}, \mathrm{TiO}_{2}$ ) show any systematic variation.

The strongest correlation with $\mathrm{LL}_{\mathrm{s}}$ is shown by $\mathrm{Al}_{2} \mathrm{O}_{3}$. There is no evidence from recovered core of either extensive alteration or alteration of a type that might be expected to lower the alumina content several percent. The most likely explanation is that the observed decrease in $\mathrm{Al}_{2} \mathrm{O}_{3}$ is an artifact of the measurement resulting from poor hole conditions (fracturing, presence of breakouts). Aluminum is determined by neutron activation using the aluminum activation clay tool (AACT), the formation being activated by a $2.35 \mathrm{MeV}$ californium source. The depth into the formation that is activated 


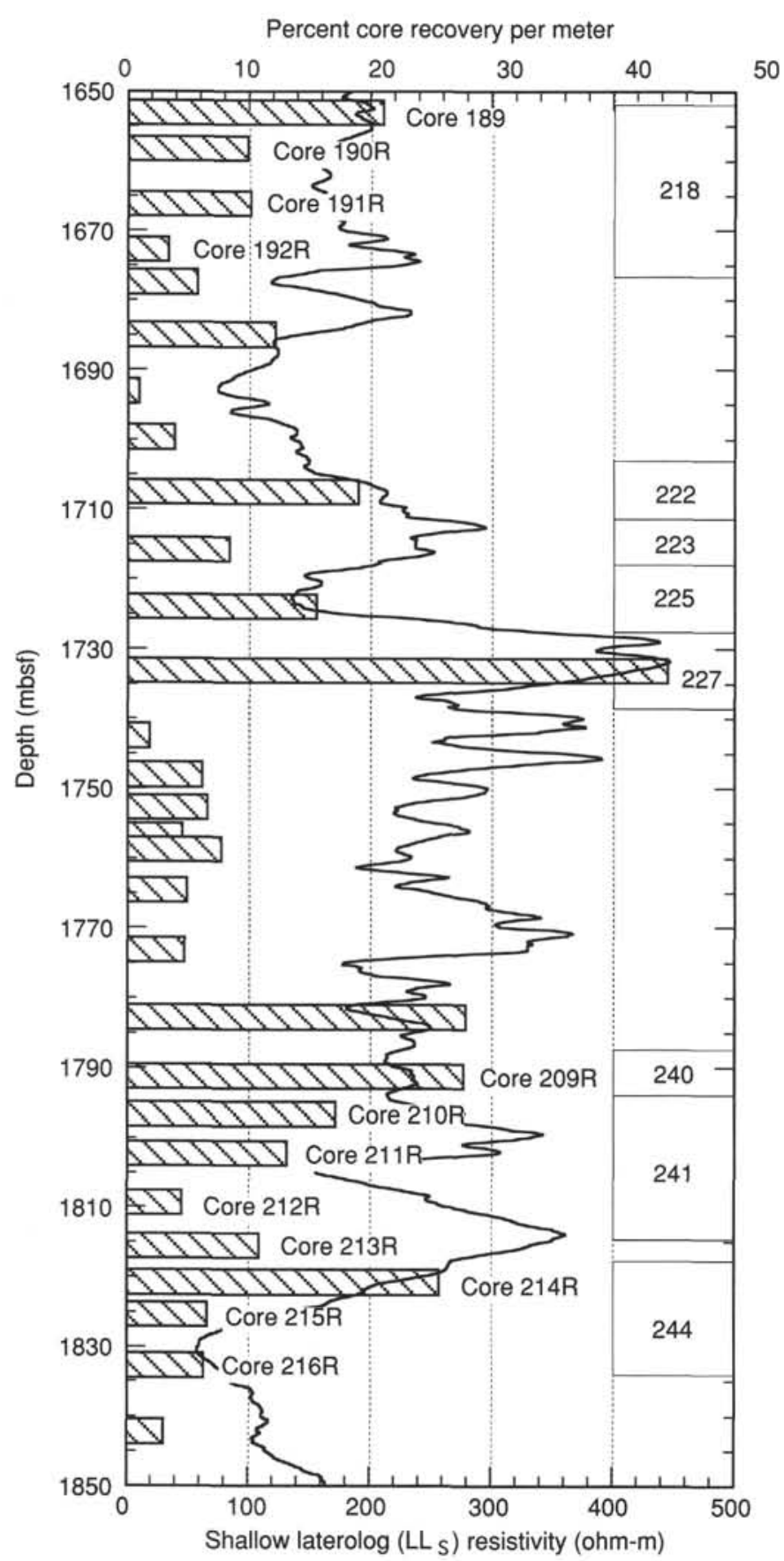

Figure 4. Expansion of part of the section shown in Figure 3 (1650 to 1850 mbsf), showing the relationship between resistivity and core recovery for Leg 140. Core recovery is scaled as percent recovery per meter cored to remove the effect of very short drilled sections. Selected shipboard defined petrographic units are shown as blocks on the right of the diagram, together with associated cores.

depends on the rock and interstitial fluid chemistry, the porosity of the formation, and the composition of the borehole fluid. A typical radius of activation for aluminum for a low porosity basalt under good borehole conditions is about $25 \mathrm{~cm}$, but under poor borehole conditions, where the amount of borehole fluid is much greater, this may drop to 5 to $10 \mathrm{~cm}$. Elements determined by the GLT ( $\mathrm{Si}, \mathrm{Fe}, \mathrm{Ca}, \mathrm{Ti}$, $\mathrm{K})$, however, are activated by higher energy ( $14 \mathrm{MeV}$ ) neutrons using a pulsed neutron generator, and have a correspondingly larger radius of activation even under poor hole conditions. For this reason alumi-

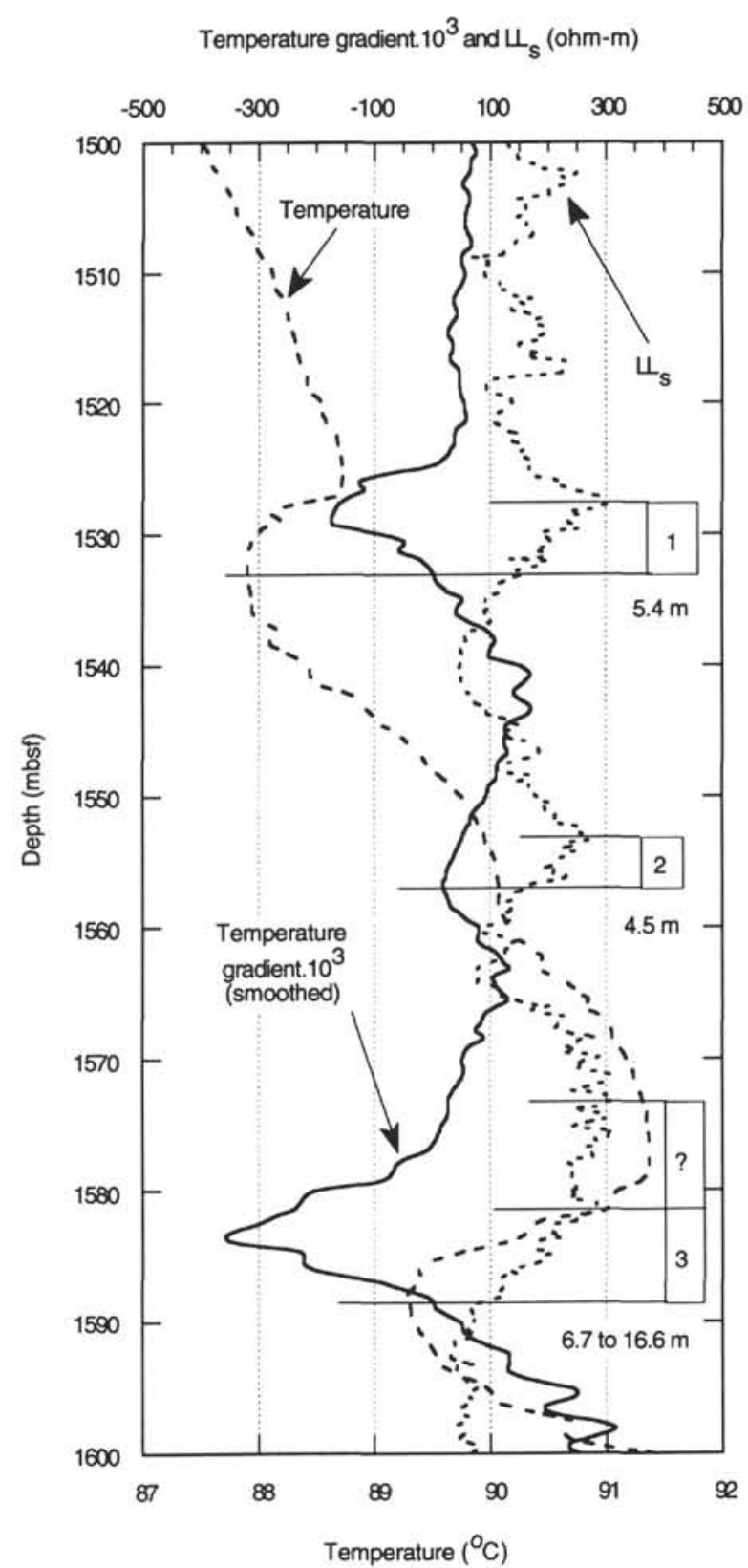

Figure 5. Detailed relationship between temperature, temperature gradient (scaled by a factor of 500), and resistivity. The actual positions of the thermal inversions are a few meters below the corresponding resistivity peaks.

num is affected much more by an increase in borehole diameter (breakout) or rugosity (fracturing) than are the other elements. In effect, an increase in borehole diameter means that more of the borehole fluid, which contains no appreciable aluminum, is measured with a consequent fall in the amount of aluminum detected. The antipathetic correlation with iron may be real and may indicate a slight build-up of oxides or sulfides (?) in the fractured zones.

\section{POSSIBLE RELATIONSHIPS TO THE SHEETED DIKE COMPLEX}

Despite the poor core recovery, Unit 241 , or at least its lower boundary, corresponds clearly with one of the resistivity/temperature inversion pairs (at about 1815 mbsf in Figs. 3 and 4). This petrographic unit is relatively coarse-grained for this section with plagioclase phenocrysts recorded at $2.5 \mathrm{~mm}$. In detail the cores covering the region 


$$
\Psi_{\mathrm{S}}(\mathrm{ohm}-\mathrm{m})
$$

10

100

1000

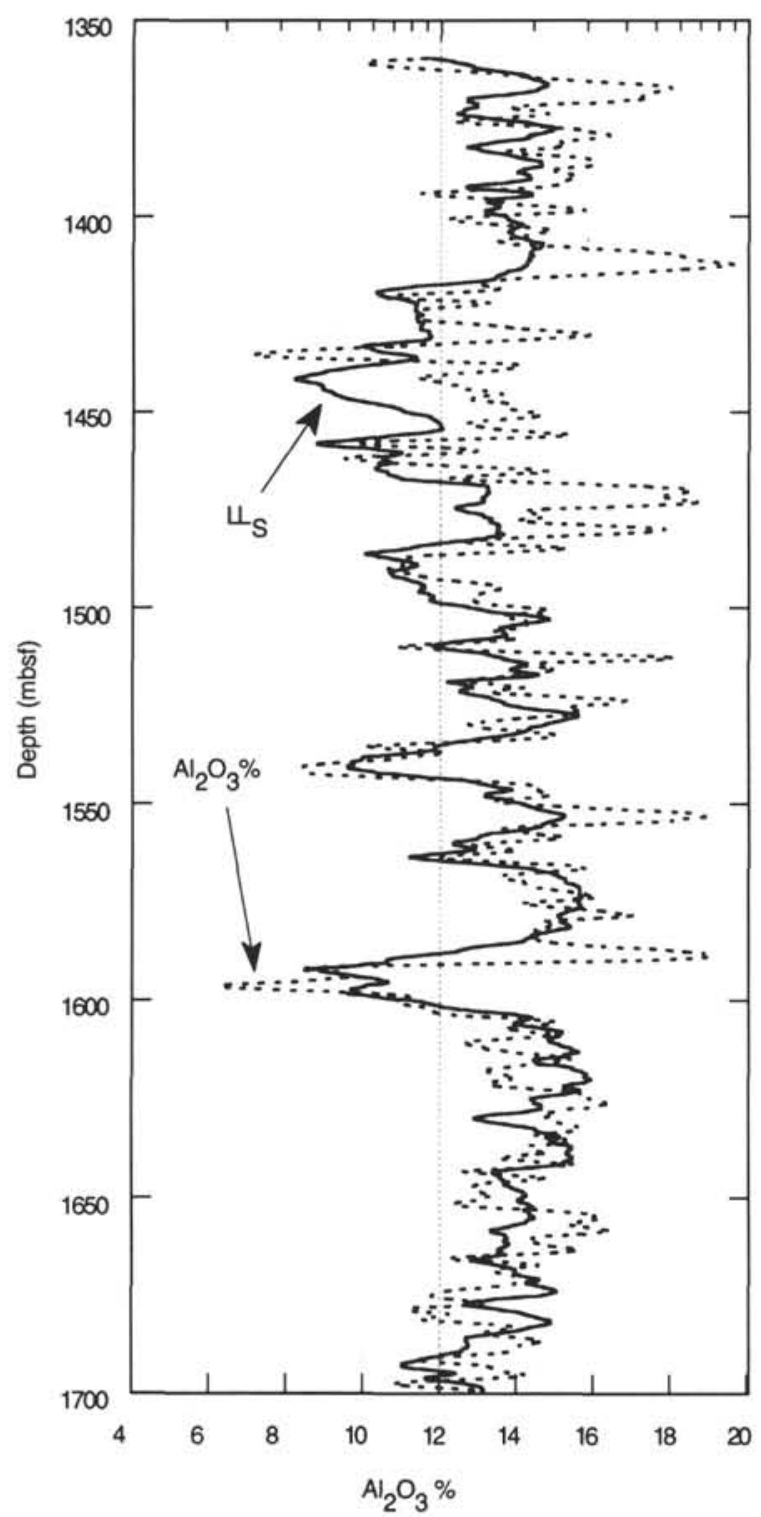

Figure 6. Variation in shallow laterolog resistivity $\left(\mathrm{LL}_{\mathrm{s}}\right)$ and $\mathrm{Al}_{2} \mathrm{O}_{3} \%$, as measured with the Geochemical Logging Tool, over the interval 1350 to 1700 mbsf. A good correlation is seen between the two curves.

of Unit 241 (Cores 210R-213R) include two resistivity "peaks" that probably represent more than one petrographically similar dike. Further, distinct and relatively coarse-grained Units 227 and 240 also correspond with major resistivity peaks and have moderately good core recovery, though obvious corresponding temperature anomalies are absent. Despite the paucity of core, the resistivity peaks are often seen to correlate with the more coarse grained and generally competent (and impermeable?) dike units, frequently with slightly higher than average core recoveries. In turn, these probably represent the more slowly cooled central parts of individual dikes, which may or may not have chilled margins, or simply individual dikes intruded into hot country rocks. Drilling from the central (coarser, more competent) part of an individual dike, or set of dikes, into a chilled margin zone will be accompanied by a change in the physical characteristics of the rock, and, in turn, its response to drilling. The temperature anomalies probably correspond to more brittle and highly fractured, chilled or fine-
$\Psi_{S}(o h m-m)$

10

100

1000

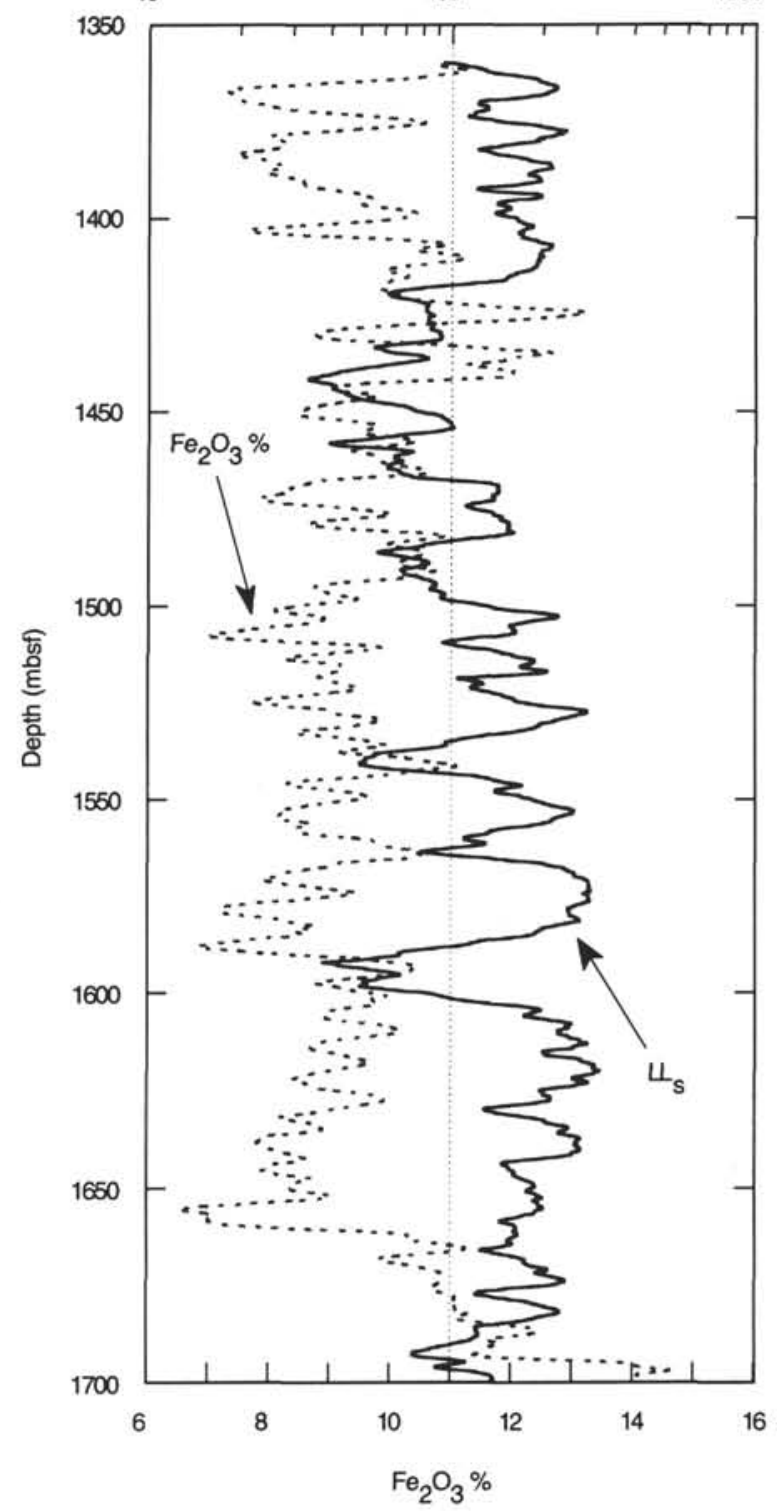

Figure 7. Variation in shallow laterolog resistivity $\left(\mathrm{LL}_{\mathrm{s}}\right)$ and $\mathrm{Fe}_{2} \mathrm{O}_{3} \%$, as measured with the Geochemical Logging Tool, over the interval 1350 to $1700 \mathrm{mbsf}$. A weak but distinct antipathetic correlation is seen between the two curves.

grained margins adjacent to the more massive central parts of some of the thicker dike units. Whereas higher core recoveries tend to be associated with the more massive units, low core recoveries tend to correlate with low resistivity zones. One result of this phenomenon is that the low resistivity zones are underrepresented in the recovered core. Detailed drilling records, particularly rates of penetration and variation in torque, should be available for analyses of this type and could be valuable in attempts to clarify these relationships.

Because of the failure of the deep laterolog, it is not possible to reach any conclusions about the geometry of these fractured zones. However, excellent $L L_{s}$ and $L L_{d}$ curves were obtained during Leg 111, and these are reproduced here in Figure 8 over the interval 1000 to 1280 mbsf, together with the Leg $140 \mathrm{LL}_{\mathrm{s}}$ curve and temperature gradient. Over this section $L_{\mathrm{d}}$ is consistently greater than $L_{\mathrm{s}}$, which indicates a dominantly vertical or high-angled fracture regime (Pezard and Anderson, 1989) at least into the top few hundred meters of the 


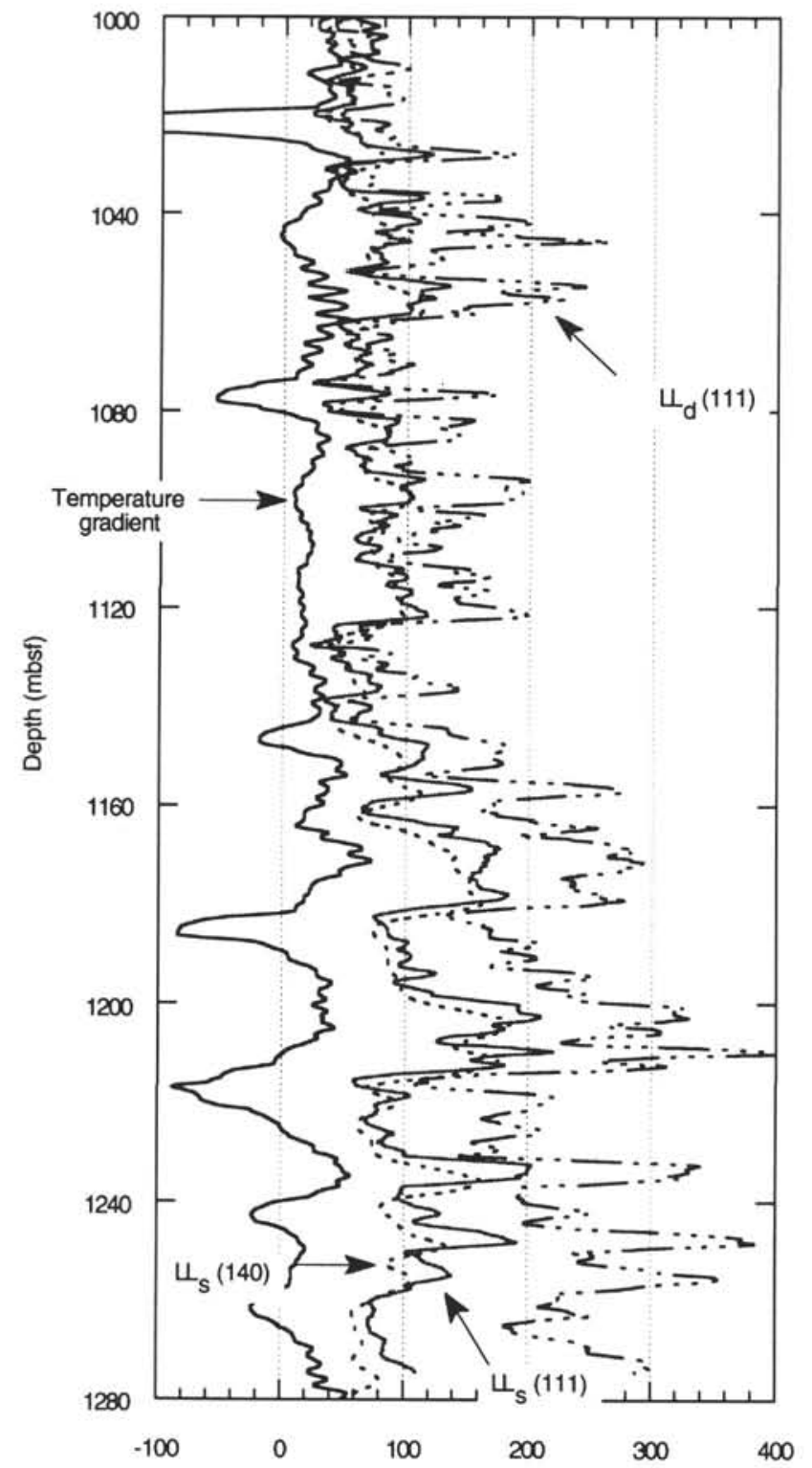

Figure 8. Comparison of laterolog data for Leg $111\left(\mathrm{LL}_{\mathrm{d}}\right.$ and $\mathrm{LL}_{\mathrm{s}}$ curves) and Leg 140 ( $\mathrm{LL}_{\mathrm{s}}$ curve only) over the interval 1000 to $1280 \mathrm{mbsf}$. A dominantly vertical or steeply dipping fracture regime is indicated for this part of the sheeted dike complex.

dike complex. Measurements of the orientation of open fractures on the core pieces showed a distinctly bimodal distribution of dip angles (Dick, Erzinger, Stokking, et al., 1992, fig. 91, "Site 504" chapter) with low-angled dips lying mostly in the range $5^{\circ}$ to $25^{\circ}$, together with a higher angled population $\left(>75^{\circ}\right)$. The low-angled fractures may be "discing" fractures (Dick, Erzinger, Stokking, et al., 1992), whereas some of the steeper fractures also may have been developed during drilling, and may be the result of hydraulic fracturing. The deep laterolog, however, responds to a fracture porosity that is much deeper into the formation, and many of the high-angled fractures are unrelated to drilling.

Given that the resistivity peaks may mark the more compact central parts of dikes or combinations of dikes without significant chilled margins, it is possible to make some suggestions about the distribution of dikes and their thicknesses, and to evaluate whether these are reasonable. Visual examination of the $\mathrm{LL}_{\mathrm{s}}$ curve (Figs. 2 and 3 ) suggests a degree of regularity in the occurrence of resistivity peaks; to a lesser extent the same may be suggested for the tempera-

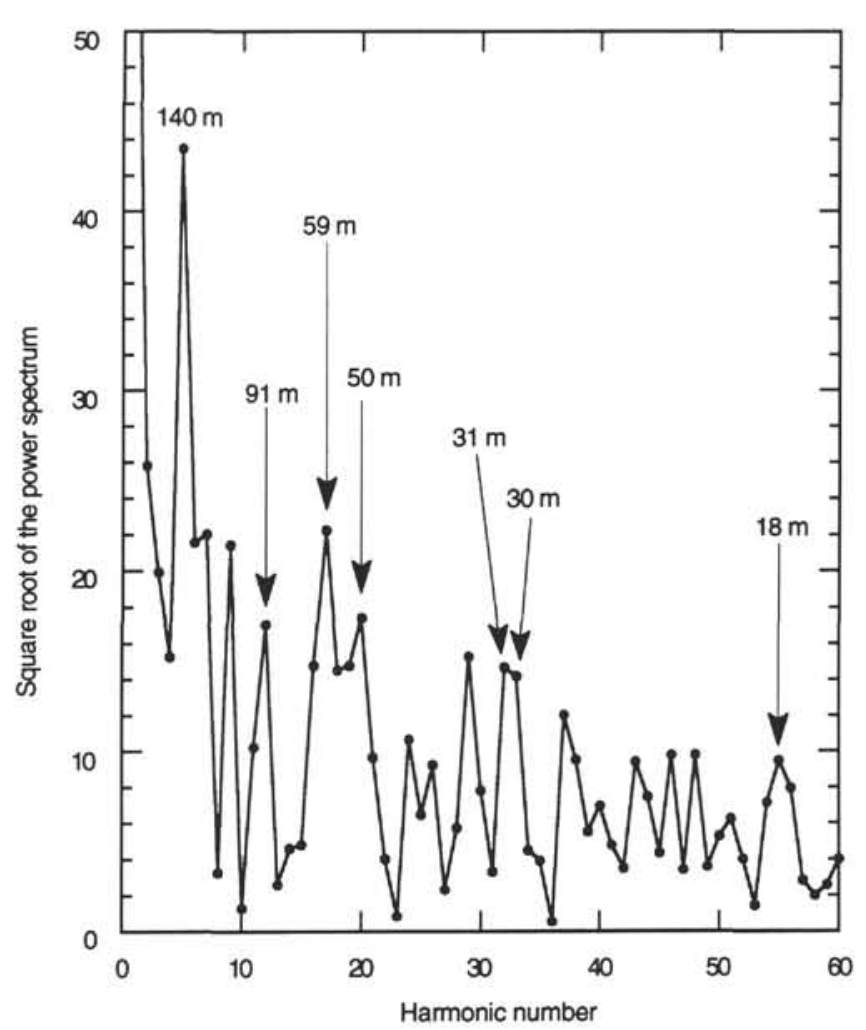

Figure 9. Summary of a Fourier analysis of the Leg 140 shallow laterolog curve: the strength of each of the first 60 harmonics is expressed as the square root of the power (or variance) spectrum. The wavelengths corresponding to selected harmonic peaks are shown, with arrows, above the peaks.

ture gradient curve. We made an attempt to verify and quantify this apparent regularity by performing Fourier analysis on each of the resistivity and temperature gradient curves. Using this approach a series of sin-cosine wave pairs of differing wavelengths is fitted to the $\log$ curves using a least squares technique. The range of wavelengths investigated varied from the whole length of the curves $(1000 \mathrm{~m}$ : 1000 to $2000 \mathrm{mbsf}$ ) down to a few meters. The results for these spectral analyses are shown in Figures 9 and 10, respectively, for the $\mathrm{LL}_{\mathrm{s}}$ and temperature gradient curves. Each plot shows the harmonic number on one axis against the square root of the power or variance spectrum on the other. The harmonic number is most easily interpreted here in terms of wavelength, so that the wavelength of the fitted ( $\sin$ and cosine) waves for the $\mathrm{i}$ 'th harmonic is $1000 / \mathrm{i}$ (that is, the length of the series divided by harmonic number). The power or variance for each harmonic (algebraically the sum of the squares of the sin and cosine amplitudes) is a measure of the strength of waves of the corresponding wavelengths in explaining the observed curve. A peak on one of these power spectra means that periodicity of the corresponding wavelength is present in the data; strong regularity on a log curve would thus appear as a distinct peak in the power spectrum, and at a wavelength corresponding to the frequency of occurrence of the regularity.

In the $\mathrm{LL}_{\mathrm{s}}$ spectrum (Fig. 9), weak peaks are present at 18, 30, 59, and $91 \mathrm{~m}$. Peaks also occur at similar wavelengths in the temperature gradient spectrum (Fig. 10). Together these indicate either a weak periodicity with these wavelengths or a periodicity that is a common factor of these wavelengths. A periodicity of 3 or $6 \mathrm{~m}$ would be compatible with these observations, and effectively divisible into the dominant wavelengths.

Available evidence from core indicates that the Hole 504B dikes are dipping at angles probably in excess of $75^{\circ}$ (dips of $79^{\circ}$ and $85^{\circ}$ were recorded for two orientated dikes in Hole 504B during Leg 140; 


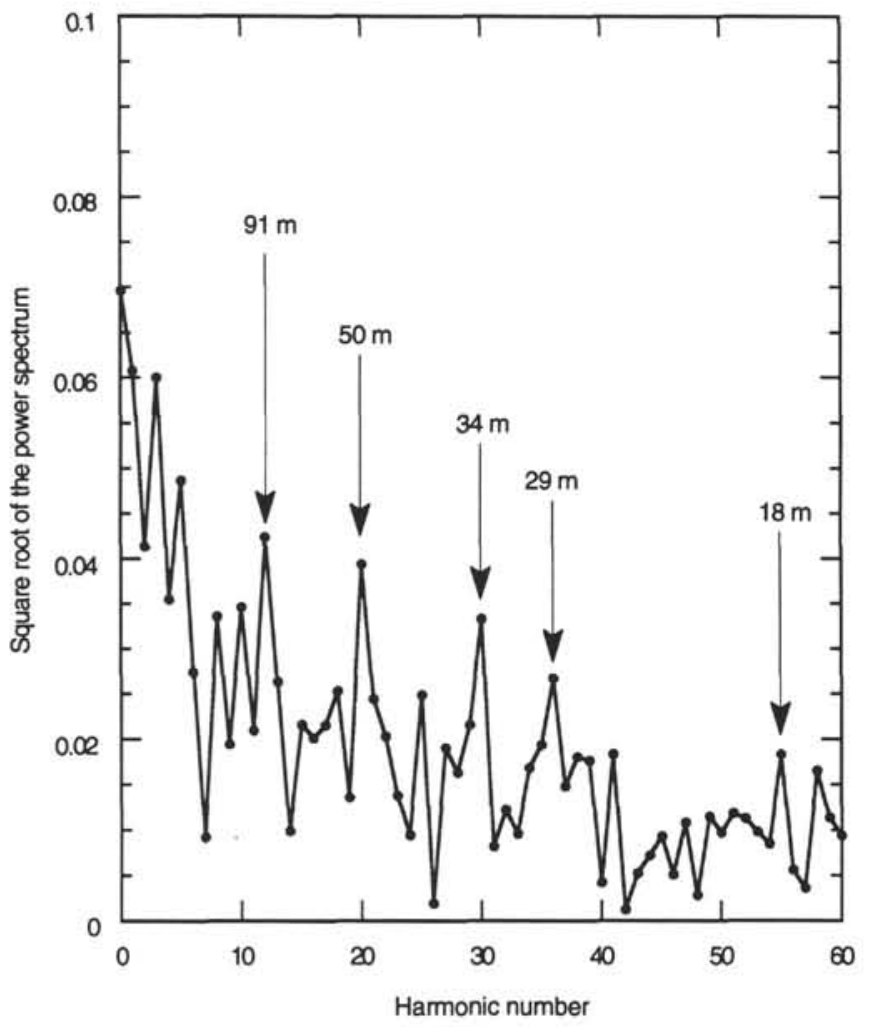

Figure 10. As Figure 9, but repeated for the temperature gradient curve.

Dick, Erzinger, Stokking, et al., 1992). With regard to the width of dikes encountered in Hole 504B, there is little direct evidence. Based on the assumption that each petrographically defined unit was a discrete dike, attempts to define the distribution of dike widths were made by Adamson (1984) for the Leg 83 data, and considerably refined with the inclusion of the Leg 111 results. The positively skewed distribution (fig. 14, Becker, Sakai, et al., 1988) has a modal value of less than $1 \mathrm{~m}$, though most dikes fall into the range 0.5 to 2 $\mathrm{m}$. Making the same assumption for the Leg 140 data: 59 petrographic units over the $378.9 \mathrm{~m}$ drilled gives an apparent (vertical) mean width of $6.42 \mathrm{~m}$, which in turn corresponds with actual widths of about 0.6 to $1.7 \mathrm{~m}$ for dikes dipping at $75^{\circ}$ to $85^{\circ}$. Considering the low core recovery in Hole $504 \mathrm{~B}$, it is perhaps surprising that the average widths for dikes we determined were close to the figures known for sheeted dike complexes elsewhere (Troodos: $1.2 \mathrm{~m}$; Bay of Islands: $1.4 \mathrm{~m}$; Kidd, 1977).

The periodicity shown by both the temperature gradient and $\mathrm{LL}_{\mathrm{s}}$ curves is consistent with apparent (vertical) dike widths of about $6 \mathrm{~m}$ and may suggest the occurrence together of small groups of dikes with similar physical properties. The repeated occurrence of groups of three or five dikes together, for instance, would generate periodicities of about 18 and $30 \mathrm{~m}$, respectively. Such a model is consis- tent with the idea of packets of dikes that have been intruded over a relatively short period of time so that the inner dikes, intruded later in the sequence, would be intruded into hotter, and probably more ductile, surroundings.

\section{CONCLUSIONS}

At the end of Leg 140, Hole 504B penetrated just over $2 \mathrm{~km}$ into the ocean floor, the lower kilometer being virtually entirely within a sheeted dike complex. Shallow laterolog resistivity, thermal gradient and some geochemical logs show a systematic and regular pattern throughout this complex. In particular, there is an strong apparent antipathy between inversions in the thermal gradient and zones of high resistivity. This relationship is a result of variations in the physical properties (fracture density and orientation, permeability, competence, grain size) of the individual dikes, or groups of a small number of dikes with similar physical properties.

In view of the low core recovery, any model for the evolution of the dike complex in Hole 504B must be consistent with observations made from the downhole measurements. Although some possibilities are discussed here, a much more complete set of wireline data is required to clarify and verify our suppositions.

\section{REFERENCES}

Adamson, A.C., 1984. Hydrothermal petrology in the Costa Rica Rift [Ph.D. thesis]. Univ. Newcastle-upon-Tyne, UK.

Becker, K., Sakai, H., et al., 1988. Proc. ODP, Init. Repts., 111: College Station, TX (Ocean Drilling Program).

Brewer, T.S., Pelling, R., Lovell, M.A., and Harvey, P.K., 1992. The validity of whole-rock geochemistry in the study of the oceanic crust: a case study from ODP Hole 504B. In Parson, L.M., Murton, B.J., and Browning, P. (Eds.), Ophiolites and their Modern Oceanic Analogues. Geol. Soc. Spec. Publ. London, 60:263-278.

Dick, H.J.B., Erzinger, J., Stokking, L.B., et al., 1992. Proc. ODP, Init. Repts., 140: College Station, TX (Ocean Drilling Program).

Harvey, P.K., and Lovell, M.A., 1989. Basaltic lithostratigraphy of Ocean Drilling Program Hole 504B. Nucl. Geophys., 3:87-96.

Kidd, R.G.W., 1977. A model for the process of formation of the upper oceanic crust. Geophys. J. R. Astron. Soc., 50:149-183.

Pezard, P.A., 1990. Electrical properties of mid-ocean ridge basalt and implications for the structure of the upper oceanic crust in Hole 504B. $J$. Geophys. Res., 95:9237-9264.

Pezard, P.A., and Anderson, R.N., 1989. Morphology and alteration of the upper oceanic crust from in-situ electrical experiments in DSDP/ODP Hole 504B. In Becker, K., Sakai, H., et al., Proc. ODP, Sci. Results, 111: College Station, TX (Ocean Drilling Program), 133-146.

\footnotetext{
Abbreviations for names of organizations and publications in ODP reference lists follow the style given in Chemical Abstracts Service Source Index (published by American Chemical Society).
}

Date of initial receipt: 15 July 1993

Date of acceptance: 15 December 1993

Ms 137/140SR-035 